\title{
ABORTION IN POST-SOVIET RUSSIA: IS THERE ANY REASON FOR OPTIMISM? *
}

\author{
BORIS DENISOV, VICTORIA SAKEVICH
}

\begin{abstract}
This paper considers the problem of abortion in modern Russia. Using official statistics, we analyze the dynamics of abortion indicators since the early 1990s. On the basis of representative national sample surveys, we conclude that official statistics are complete and reliable. This in turn confirms the steady decline of abortions during the post-Soviet years.

A particularly rapid decline in abortions is seen among the youngest women. Modern teenagers have fewer abortions than their predecessors at this age. The current level of induced abortions in women under age 20 in Russia today is less than in France, Great Britain, Sweden, and a number of other developed countries of European culture.
\end{abstract}

The major differentiating factor for frequency of abortion is age. There are no clear correlations between the risks of abortion in Russia and such standard social characteristics as income, type of settlement and education. Despite the positive trend, Russia remains one of the countries with the highest abortion rates in the world.

The country's turn to traditional values and the allegedly growing role of religion are inadequate mechanisms to reduce abortions. Government support is given not to proven, evidence-based measures like the promotion of family planning, sex education, etc., but to repression and restrictions. During the past 10 15 years, a number of restrictive amendments have been introduced into legislation. The authors indicate the counterproductive effects of these restrictions on abortion as an instrument of a pronatalist population policy.

This article recommends paying more attention to improvements in the quality of abortion provision by the introduction of modern medical standards and protocols. In the conclusion, the authors suggest ways to improve the official statistics on abortions.

Key words: pregnancy termination, abortion, birth control, family planning, reproductive health.

Federal and regional legislative initiatives to limit access to abortions appear in Russia on an incredibly regular basis [Sakevich 2011; 2012]. A complete ban on abortion has often been proposed, an exception being made only for cases when pregnancy endangers the life or health of a woman [Sakevich 2013].

The question arises as to whether the abortion issue is really so acute in Russia today, and if so, whether the enhancement of abortion legislation can contribute to its solution and lead to a general improvement of the demographic situation. The authors aim at answering these questions with the help of official statistics and the results of a few representative national surveys.

Boris P. Denisov. Department of Economics, Lomonosov Moscow State University. Russia.

Victoria I. SAKEVICH. Institute of DEMography, National RESEARCH University Higher SchoOl of ECONOMICS. Russia. E-MAIL: vsakevich@hse.ru.

TRANSLATED FROM: ДЕМОГРАФИЧЕСКОЕ ОБОЗРЕНИЕ. 2014, 1(1): 144-169. ORIGINAL TITLE: “АБОРТЫ В ПОСТСОВЕТСКОЙ РОССИИ: ЕСТЬ ЛИ ОСНОВАНИЯ ДЛЯ ОПТИМИЗМА ” (HTTP://DEMREVIEW.HSE.RU/EN/2O14-1/120991286.HTML).

* This Study was implemented under “The National Research University Higher School of Economics Academic FUND” PROGRAM FOR 2013-2014, RESEARCH GRANT № 12-01-0076. 


\section{DYNAMICS OF ABORTIONS}

In the Soviet Union, abortion played an important role in birth control. The USSR, with Russia as a constituent part, was the world's leader in the frequency of abortions [Avdeev, Blum, Troitskaja 1995; Vishnevsky, Sakevich 2006].

Since the late 1980s, the number of pregnancy terminations in Russia has been steadily declining (Figure 1). From 1988 to 2012, both the absolute number and the abortion rate (per 1,000 women of reproductive age) fell fourfold.

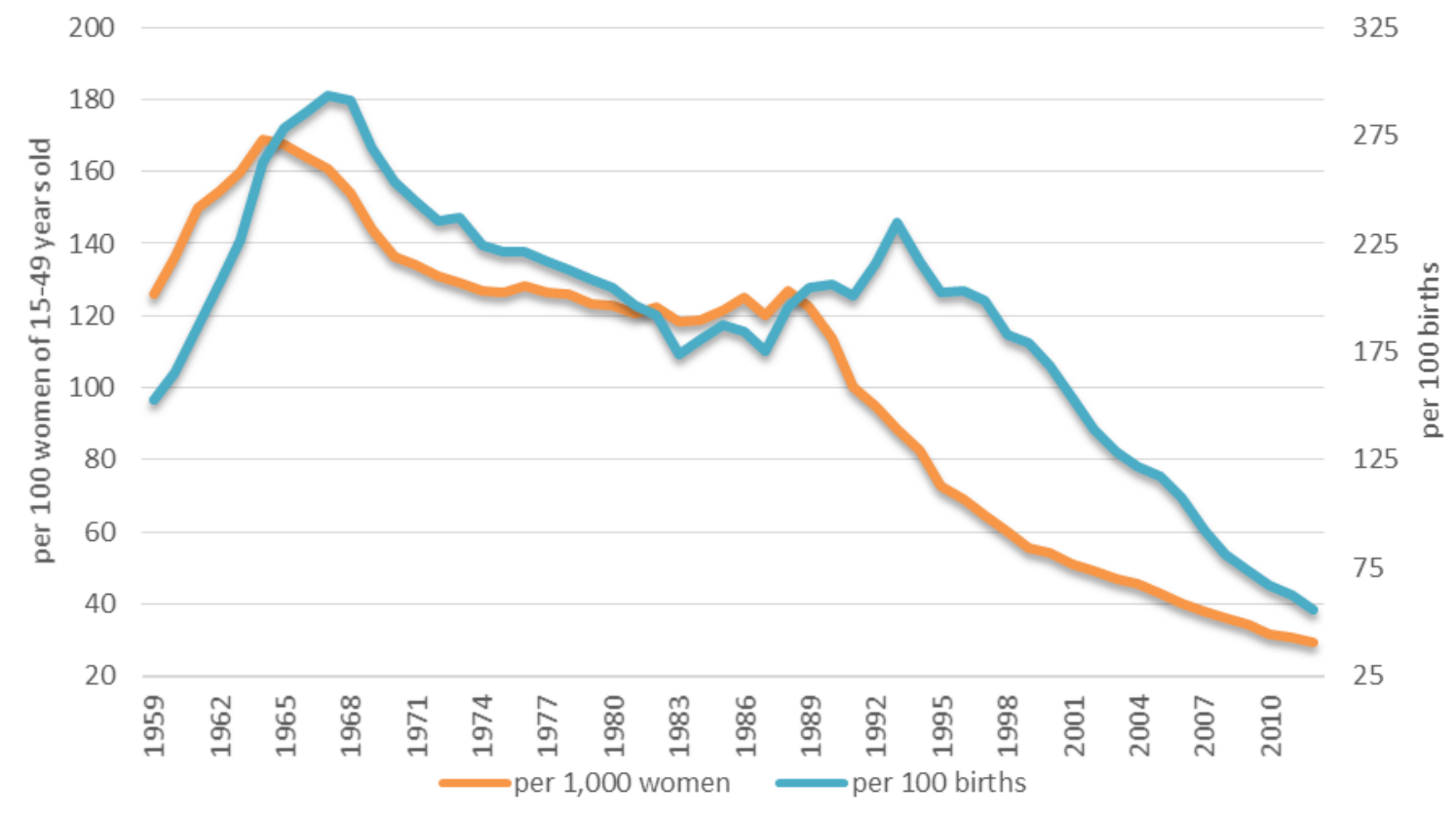

Figure 1. Abortions per 1,000 women of reproductive age and per 100 births in Russia, annual data, 1959-2012

Source: [Rosstat 2013b].

Official abortion statistics (Table 1) are published by both the Federal State Statistics Service (Rosstat) and the Ministry of Health. Rosstat accounting is more complete because Rosstat, along with abortions registered in medical facilities within the jurisdiction of the Ministry of Health, also takes into consideration abortions carried out in health facilities of other government ministries and departments, as well as in private health care facilities.

In 2012, the Federal State Statistics Service registered 1.06 million terminated pregnancies or 29.3 per 1,000 women of reproductive age, whereas in 1990, for example, over 4 million abortions (114 per 1,000 women) were carried out in Russia.

Most abortions in Russia are carried out in facilities under the jurisdiction of the Ministry of Health. In 2012, the Ministry of Health of the Russian Federation recorded 935.5 thousand abortions, or $88 \%$ of the total. The role of other organizations in providing abortions is relatively small. In 2012, the private health sector was involved in about $10 \%$ of all abortions, on average. This proportion varies by region, from zero in 15 Russian regions to more than a quarter in others. In 2012, the largest share of abortions performed in private clinics was registered in the Buryat 
Republic (27\%), Ulyanovsk (25\%), Moscow (24\%), Tambov (24\%), Nizhny Novgorod (22\%) and Omsk $(22 \%)$ regions. The lowest share of abortions performed in private clinics was observed in the North Caucasus and Southern Federal Districts: 3\% and 5\% on average, respectively.

Table 1. The official statistics of abortions, Russia: 1990, 1995, 2000, and 2005-2012

\begin{tabular}{|c|c|c|c|c|}
\hline \multirow[b]{3}{*}{ Year } & \multicolumn{4}{|c|}{ Number of abortions } \\
\hline & \multicolumn{3}{|c|}{ Rosstat data } & \multirow[b]{2}{*}{$\begin{array}{c}\text { Data of the Ministry of } \\
\text { Health, thousands }\end{array}$} \\
\hline & $\begin{array}{l}\text { Total, } \\
\text { thousands }\end{array}$ & $\begin{array}{c}\text { per } 1,000 \text { of } \\
15-49 \text { year old } \\
\text { women }\end{array}$ & per 100 live births & \\
\hline 1990 & $4,103.4$ & 113.9 & 206 & $3,920.3$ \\
\hline 1995 & $2,766.4$ & 72.8 & 203 & $2,574.8$ \\
\hline 2000 & $2,138.8$ & 54.2 & 169 & $1,961.5$ \\
\hline 2005 & $1,675.7$ & 42.7 & 117 & $1,501.6$ \\
\hline 2006 & $1,582.4$ & 40.3 & 107 & $1,407.0$ \\
\hline 2007 & $1,479.0$ & 38.1 & 92 & $1,302.5$ \\
\hline 2008 & $1,385.6$ & 36.1 & 81 & $1,236.4$ \\
\hline 2009 & $1,292.4$ & 34.1 & 73 & $1,161.7$ \\
\hline 2010 & $1,186.1$ & 31.7 & 66 & $1,054.8$ \\
\hline 2011 & $1,124.9$ & 30.5 & 63 & 989.4 \\
\hline 2012 & $1,064.0$ & 29.3 & 56 & 935.5 \\
\hline 1990 - 2012, -fold & 3.9 & 3.9 & 3.7 & 4.2 \\
\hline
\end{tabular}

In 2007, for the first time in the observation period, the annual number of births in Russia exceeded the annual number of terminated pregnancies; in subsequent years, this gap widened largely due to a significantly rising number of births. By 2007, the abortion ratio had fallen to 92 per 100 live births, and by 2012, to 56 abortions per 100 births (Table 1). For a long time, twothirds of pregnancies in Russia ended in abortions (assuming that the number of pregnancies equals the sum of births and recorded abortions). The ratio began to change after 2000, when the number of births began to grow, while the number of abortions continued to decline; in 2012, just over one-third of pregnancies ended in abortion. As is seen in Figure 2, the birth and abortion curves are not parallel. There was a time when both births and abortions decreased (in the 1990s); in recent years, the dynamics of abortions and births move in opposite directions, but there is no reason to say that the number of births is increasing due to the reduction of abortions.

The total abortion rate - an integral index which does not depend on the age structure of female populations - decreased from 3.39 abortions per woman of reproductive age in 1991 to 0.97 in 2012. 


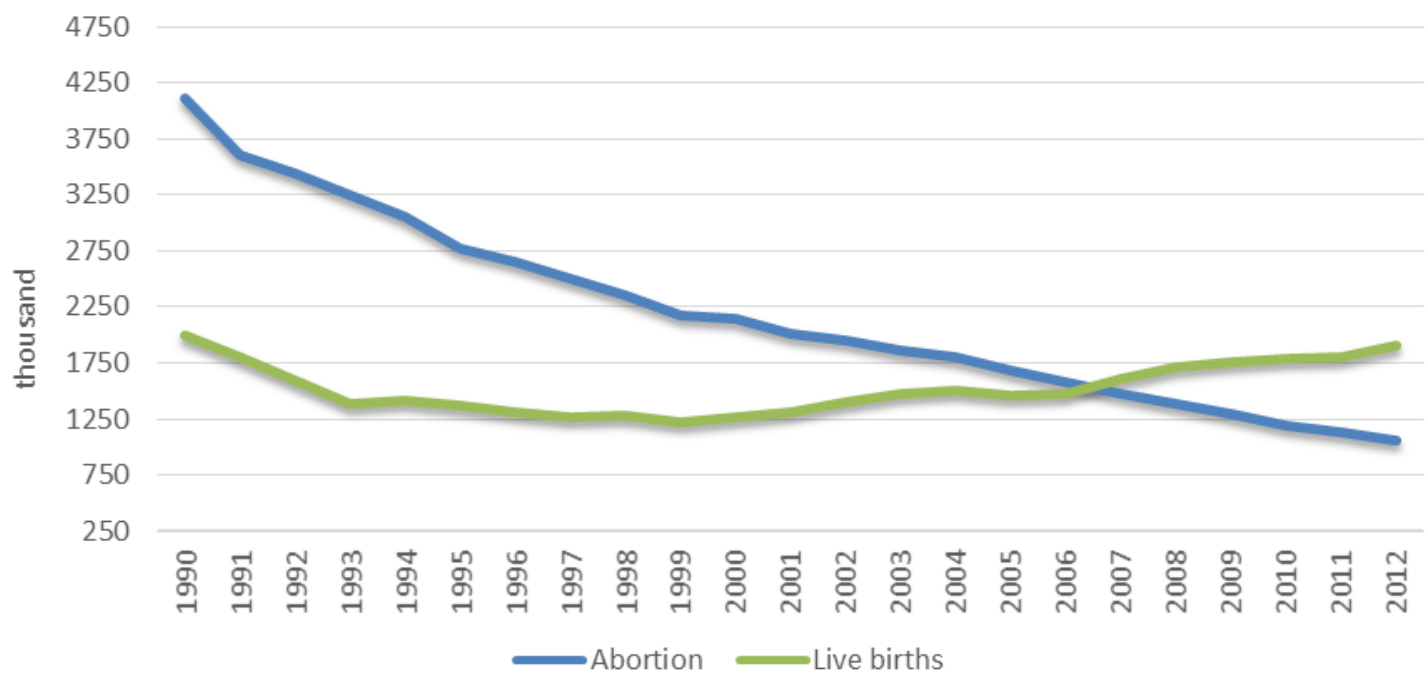

Figure 2. Annual number of live births and abortions in Russia, 1990-2012

Source: Rosstat

Despite favorable dynamics, Russia is still among the world's leaders in terms of the number of terminated pregnancies; the current Russian level is 2-4 times higher than in Belgium, Germany, the Netherlands and Switzerland [Sedgh et al. 2011]. The growing gap between Russia and neighboring Belarus is particularly impressive: in the early 1990s, the abortion rates were approximately similar in the two countries, while in 2012, the rate in Belarus was half the rate in Russia (Figure 3) [Denisov, Sakevich, Jasilioniene 2012].

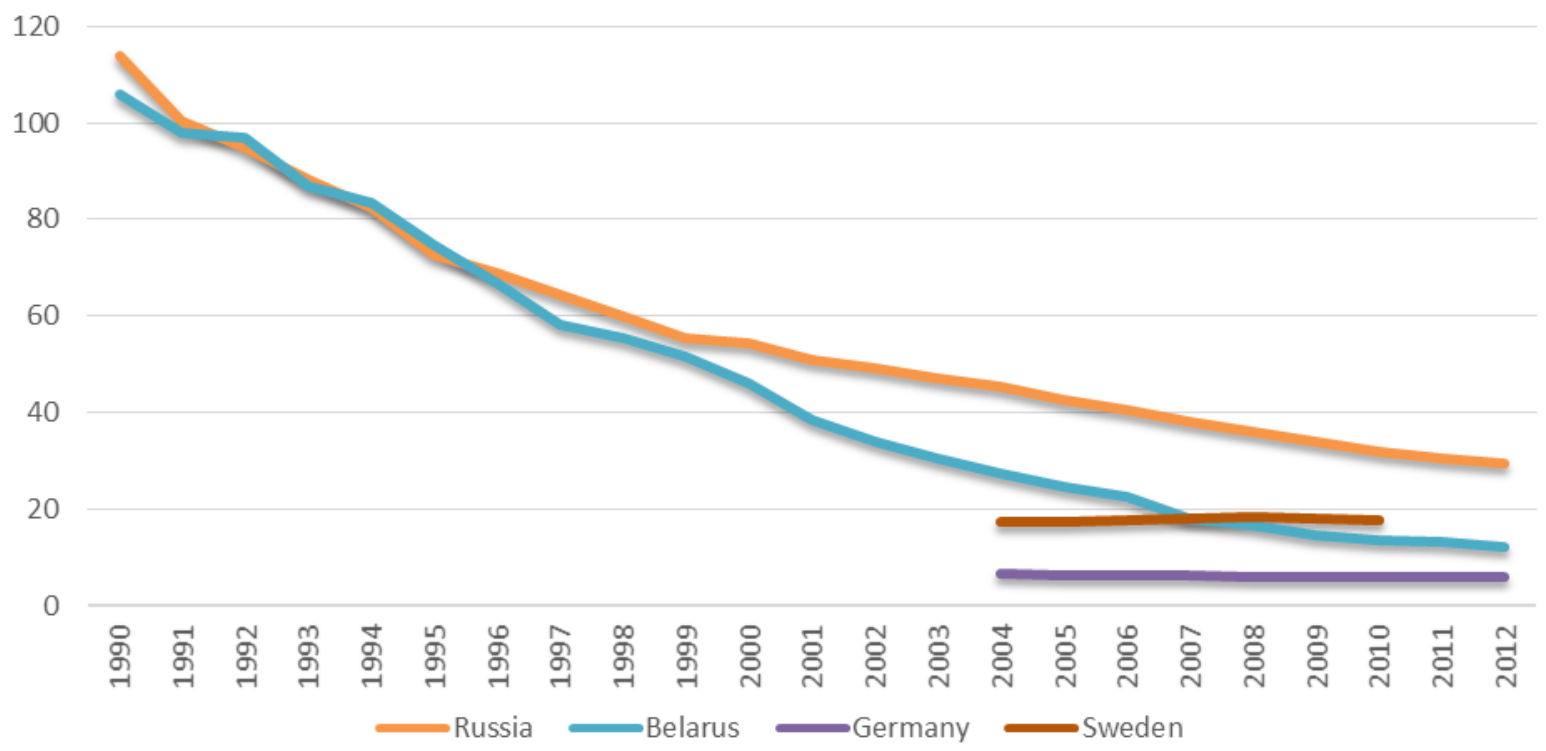

Figure 3. Number of abortions per 1,000 women of reproductive age (15-49) in Russia, Belarus, Germany and Sweden

Notes: Data on Russia and Belarus include spontaneous abortions.

Sources: [Rosstat 2013b; National Statistic... 2013; Eurostat Database 2014]. 


\section{How Reliable Are Official Statistics?}

Official abortion data is often questioned even by senior government officials. It is commonly suggested that the data is distorted by widespread private health services in the country. ${ }^{1}$ In our opinion, the underestimation of abortions is exaggerated. Non-governmental organizations with a license for medical services (including abortion) are obliged to provide data on their work to local offices of the Federal State Statistics Service; when concealing any part of their activities, they violate the law and expose themselves to unnecessary risk.

The accuracy of the official statistics of abortions can be confirmed or refuted through sample population surveys. National surveys addressing the issue of pregnancy termination are not numerous, but they are available. The 19th wave of the Russian Longitudinal Monitoring Survey of the Higher School of Economics (RLMS-HSE) ${ }^{2}$ (end of 2010) contained a special module related to women's reproductive health. Respondents aged 15-55 were asked whether they had had an abortion during the 12 months before the survey, and if so, how many abortions they had undergone. The abortion rate calculated on the basis of their responses reached 26.9 (confidence interval: 23.9-29.9) per 1,000 women of reproductive age, ${ }^{3}$ while the official rate for 2010 was higher -31.7 per 1,000 women. Yet, it should be taken into account that the official statistics of abortions in Russia include spontaneous abortions (miscarriages), which began outside a medical facility and led to hospitalization, as well as so-called "unspecified" out-of-hospital abortions, about which there is not sufficient information available to categorize them as either spontaneous or induced. If we exclude spontaneous abortions, then the official rate in 2010 will decrease from 31.7 to 27.1 per 1,000 women, and if we do not take into account miscarriages and unspecified abortions, then the abortion rate will reach 25.7 per 1,000 women of reproductive age. Hence, RLMS-HSE results (26.9: 23.9-29.9) and Rosstat data (25.7-27.1) are very close.

Moreover, according to the RLMS-HSE data, about 13\% of abortions during the year prior to the survey were made in private clinics, which is quite consistent with the Rosstat data on the abortion providers.

In 2011, a national Sample Survey of Reproductive Health (SSRH) of women was carried out for the first time in Russian (and Soviet) history ${ }^{4}$; its data are not yet freely available for

\footnotetext{
${ }^{1}$ For example, Vice President of the Russian Academy of Medical Sciences A.A. Baranov states that the official figures underestimate the true number of abortions by a factor of at least two. [cited by: Radzinsky 2013: 6]. E. Mizulina (State Duma M.P.) claims that the annual number of abortions in Russia remains at 5 million (RIA Novosti News Agency, November 10, 2013, URL: http://ria.ru/society/20131110/975842743.html). Deputy Prime Minister O. Golodets, speaking at the Fifteenth International Scientific Conference of the Higher School of Economics, noted: "There is an ascending trend in the number of abortions, including in happy families" (URL: http://conf.hse.ru/2014/news/119037590.html). The Guttmacher Institute (USA), which regularly prepares a global review of abortions, considers Russia a country with incomplete abortion statistics. This incompleteness, in the opinion of review authors, is related to the rise of private clinics in Russia [Sedgh et al. 2011].

2 "Russian Longitudinal Monitoring Survey of the Higher School of Economics is a series of annual, nationally representative household surveys based on probabilistic, stratified, multistage, areal selection. It is an international research project carried out by the Higher School of Economics, the Population Center of North Carolina University in Chapel Hill (USA) and the Institute of Sociology of the Russian Academy of Sciences (URL: http://www.hse.ru/rlms/).

3 Here and below, the calculations of the authors are based on the RLMS-HSE database (URL: http://www.hse.ru/rlms/).

${ }^{4}$ The study was conducted by the Federal State Statistics Service (Rosstat) in cooperation with the Ministry of Health of the Russian Federation, and with the financial support of the United Nations Population Fund (UNFPA) and the
} 
Russian researchers. According to SSRH, the abortion rate (including spontaneous abortions) during the three years preceding the survey reached 34 per 1,000 women aged 15-44 [Rosstat 2013a: 53], which is lower than the rate according to official statistics -37.9 , on average, per 1,000 women aged 15-44 in 2009-2011.

The similarity of survey data and abortion statistics of Rosstat was shown previously for regional studies [Philipov et al. 2004]. Hence, it can be concluded that there is no significant underestimation of the number of abortions in Russia, and that the significant decrease in abortions over the past two decades was real.

\section{WHICH WOMEN ARE AT HIGHEST ABORTION RISK?}

Russia differs from other countries not only in the level of abortions, but also in the age distribution of abortions (Figure 4). Russia drastically differs from Anglo-Saxon and Scandinavian countries, where abortion is an issue of concern primarily with respect to adolescents. In recent years, the proportion of 15-19-year-olds among the total number of women having abortions has reached $20 \%$ in the United Kingdom, 18\% in Finland, and 17\% in Denmark, Norway, Sweden and the United States, but only $8 \%$ in Russia.

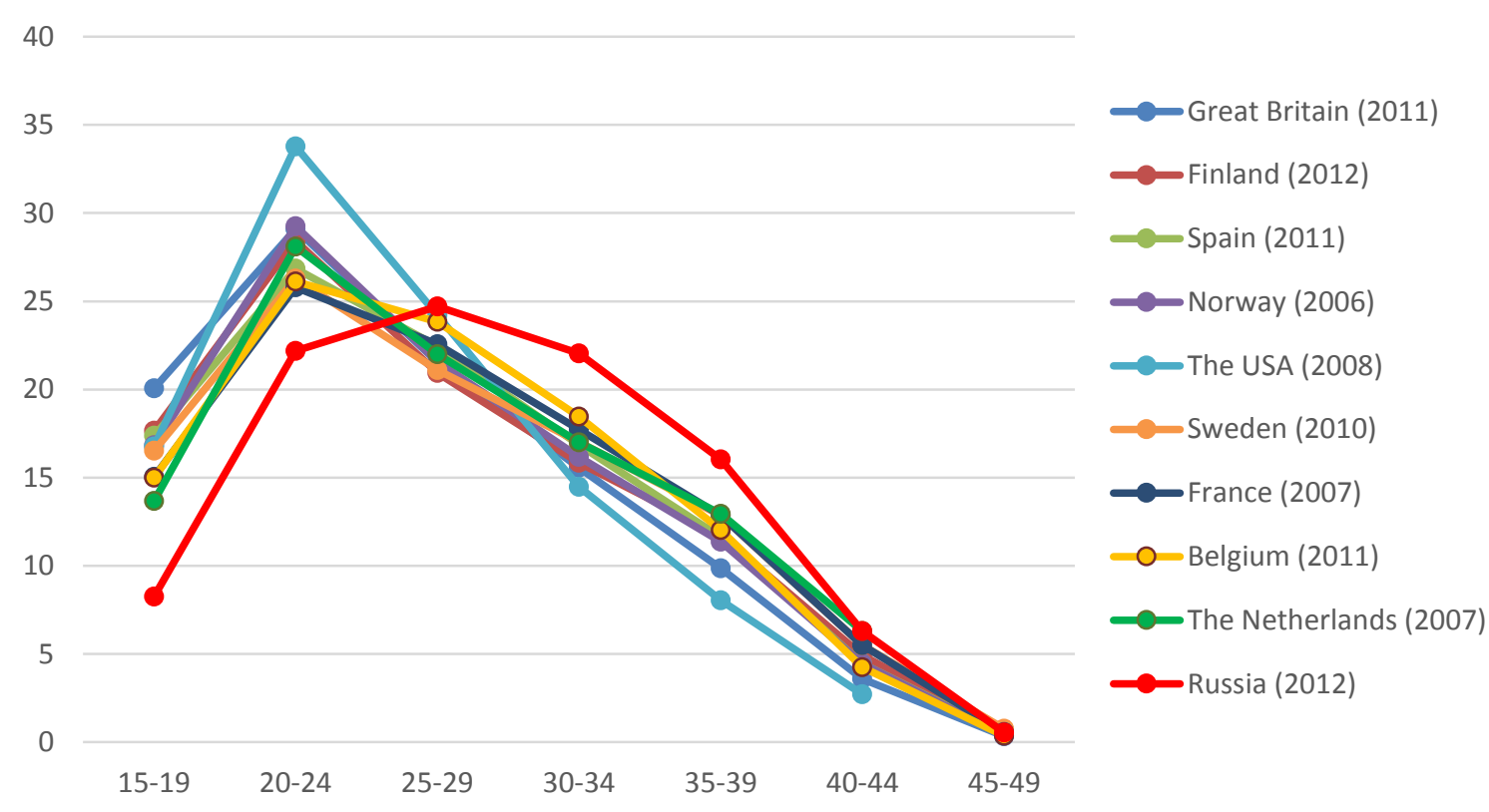

Figure 4. Age distribution of abortions in Russia and some other countries, \% (in brackets - observation year)

Sources: Based on [Eurostat Database 2014].

The highest abortion rate in Russia (as well as the highest fertility rate) is observed in the age group 25-29 (Tables 2 and 3); a quarter of abortions occur in this age group. Women aged 20-

United States Agency for International Development (USAID). The field survey in 60 regions of Russia was carried out by the Information and Publishing Center "Statistics of Russia". Technical assistance in conducting the survey was provided by the Department of Reproductive Health of the Centers for Disease Control and Prevention (CDC), Atlanta, GA, USA. The survey was based on personal interviews with women of reproductive age (15-44) at their places of residence. 10,010 answers were received. 
24 and 30-34 are characterized by roughly similar abortion rates, and their respective contributions to the total number of abortions are $22 \%$.

Abortion in Russia aims at birth spacing or birth stopping by marital couples more often than at delaying an unmarried girl's first birth. The average age of women terminating pregnancy in 2012 was 29.37 years as compared with 28 years in 1996 when the data became available. Thus, we observe the "aging" of both fertility and abortion in Russia. Young people use modern contraception more often, thus making family planning among them more efficient [Sakevich 2009].

Abortion rates decreased in all age groups throughout the post-Soviet period (Table 2). From 1991 to 2012, the abortion rate was reduced by a factor of 4.4 among women under the age of 20, by a factor of 3.4 for women aged 20-34, and 3.3 for women aged 35 and older.

Over the last twenty years, the abortion rate in the age range of 20-34 years decreased almost linearly. The periods 1995-1999 and 2009-2012 were marked by a particularly rapid reduction (by $10 \%$ per year) in the number of abortions among women under 20, while in 20002008 the average annual rate of decline was 4\%. In 2012, the abortion rate in the age group 15-19 almost equaled the abortion rate of those 35 and older, while in the mid-1990s it was 1.7 times higher. The first period of rapid decline in teenage abortions coincides with the Presidential Program "Family Planning"; subsequently, no special efforts have been made to promote responsible parenthood. Research under the auspices of the WHO Regional Office for Europe revealed a trend towards a reduction in sexual activity among Russian secondary school students [Currie et al. 2012]. But this is not enough to explain the irregularities in the reduction in abortions among adolescents; the issue requires further study. Yet the rapid decline in abortions among young women is encouraging: the "abortion culture", if it existed, is passing away among postSoviet generations.

Russia left the group of world leaders in the frequency of induced abortions among adolescents, but it is still far from being among the most advanced countries (Figure 5). In recent years, the highest abortion rates in the 15-19 age group have been observed in the United States, Sweden, Estonia, Bulgaria, England and Wales and Romania. The success of Belarus is noteworthy as well: the level of teenage abortions has decreased to that of the Netherlands, a country that has been regarded for many years as an example of well-being in terms of reproductive health.

Official statistical sources do not provide much data on socio-demographic characteristics of women undergoing abortion: there is no segmentation into urban and rural residents, married and unmarried women, etc. This information can be obtained from sample surveys only. According to the results of the $19^{\text {th }}$ wave of the RLMS-HSE, there is no significant difference between abortion rates in cities and those in the countryside. $39 \%$ of urban women and $36 \%$ of rural women of reproductive age (15-49 years) have had at least one abortion; the average number of abortions among those who have had at least one is 2.1 per woman in urban areas and 2.4 abortions per woman in rural areas. 
Table 2. Age-specific abortion* rates and total abortion* rate, Russia: 1991, 1995, 2000, and 2010-2012.

\begin{tabular}{l|rrcc|c}
\hline \multirow{2}{*}{ Year } & \multicolumn{4}{|c|}{ Abortions per 1,000 women by age group } & \multirow{2}{*}{ Total abortion rate*** } \\
\cline { 2 - 4 } 1991 & $15-19^{* *}$ & $20-34$ & 35 and older & \\
\hline 1995 & 69.7 & 152.5 & 50.5 & 3.39 \\
2000 & 57.1 & 122.4 & 33.1 & 2.62 \\
2010 & 36.0 & 97.6 & 23.8 & 2.00 \\
2011 & 19.1 & 49.5 & 15.2 & 1.07 \\
2012 & 17.2 & 47.1 & 15.2 & 1.02 \\
Decrease from 1991 to 2012, factor & 15.7 & 44.7 & 15.1 & 0.97 \\
\hline
\end{tabular}

* Including spontaneous abortions.

** Including abortions among girls under 15 years of age.

*** The average number of induced abortions a woman would have during her reproductive life, provided that age-specific abortion rates of the observation year remain unchanged.

Notes: In 1991 - 2008, Rosstat published data on abortion by enlarged age groups. Since 2008, Rosstat has been publishing abortion rates by five-year age groups.

Source: Based on Rosstat data.

Table 3. Age-specific abortion indicators*, Russia: 2008-2012.

\begin{tabular}{lccc|c|c|c|c}
\hline Year & $15-19 * *$ & $20-24$ & $25-29$ & $30-34$ & $35-39$ & $40-44$ & $45-49 * * *$ \\
\hline \multicolumn{2}{l}{ Age-specific } & abortion rates & per 1,000 & women & of the specified age group & & \\
2008 & 25.3 & 57.9 & 62.6 & 52.7 & 37.0 & 13.8 & 1.2 \\
2009 & 21.9 & 53.1 & 58.4 & 50.1 & 35.2 & 13.7 & 1.1 \\
2010 & 19.1 & 48.1 & 53.8 & 46.5 & 33.0 & 12.9 & 1.1 \\
2011 & 17.2 & 45.3 & 51.1 & 44.5 & 32.0 & 12.7 & 1.1 \\
2012 & 15.7 & 42.7 & 48.2 & 42.8 & 31.2 & 12.4 & 1.1 \\
Contribution of age groups to the total abortion rate, $\%$ & & & & \\
2008 & 10.1 & 23.1 & 25.0 & 21.0 & 14.8 & 5.5 & 0.5 \\
2009 & 9.4 & 22.7 & 25.0 & 21.5 & 15.1 & 5.9 & 0.5 \\
2010 & 8.9 & 22.4 & 25.1 & 21.7 & 15.4 & 6.0 & 0.5 \\
2011 & 8.4 & 22.2 & 25.1 & 21.8 & 15.7 & 6.2 & 0.5 \\
2012 & 8.1 & 22.0 & 24.9 & 22.1 & 16.1 & 6.4 & 0.5 \\
\hline
\end{tabular}

* Including spontaneous abortions.

** Including abortions among women under the age of 15.

*** Including abortions among women over the age of 49.

Source: Based on Rosstat data. 


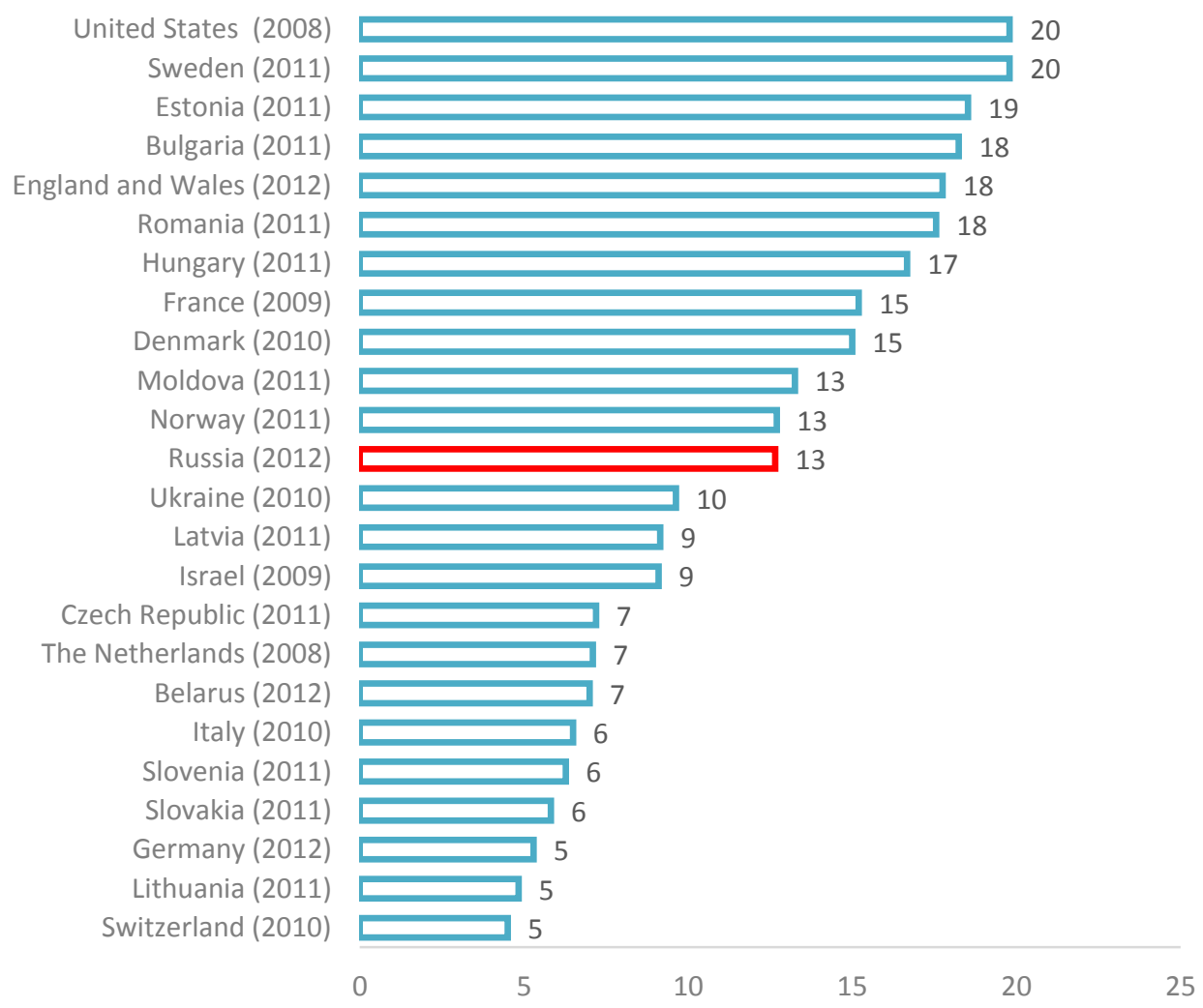

Figure 5. Abortion rate in age group 15-19 in Russia and selected countries, per 1,000 women

Notes: Data on Russia do not include spontaneous abortions.

Sources: [UNICEF 2013]; national statistical agencies, Guttmacher Institute (US data).

Abortion rates differ by level of education. According to the RLMS-HSE, more educated women are less likely to terminate their pregnancies: $41.8 \%$ of women aged 25-49 with tertiary education have had abortions, as opposed to $54.2 \%$ of women without a higher education diploma. But highly educated women are also characterized by a relatively high abortion rate: by the end of the reproductive period, $66 \%$ of women with higher education have had an abortion. Hence, the Russian population is relatively homogeneous with respect to abortion rates.

According to previous research, exposure to the risk of abortion in Russia is only loosely determined by such conventional social characteristics as type of settlement, income, and education [Denisov, Sakevich 2009].

\section{Abortions AND Reproductive Health}

According to the WHO, when performed by skilled providers using correct medical techniques and drugs under hygienic conditions, induced abortion is a very safe medical procedure" [WHO 2013: 21]. Current research does not confirm negative impacts of (legal) abortions on subsequent pregnancies and risks of acquiring breast cancer. The same WHO report also states that the negative psychological effects of abortion were noted for few women, and most of them are more likely to be the continuation of preexisting conditions than the result of induced abortion [WHO 
2013: 50]. The shorter the period between conception and abortion, the lower the likelihood of adverse effects on women's health.

Under Russian law, abortion is permitted at the woman's request with pregnancy duration of less than 12 weeks, for selected "social" reasons when the pregnancy does not exceed 22 weeks and for medical reasons - regardless of the length of pregnancy. The provision of abortion-related medical care (at any stage of pregnancy) is part of the state-guaranteed medical services provided to Russian citizens free of charge and included in the program for state-guaranteed free medical care to Russian citizens; in other words, such care should be provided free of charge in public health organizations. Russian legislation on abortion remains one of the most liberal in the world.

In the facilities supervised by the Ministry of Health, most abortions (96\% in 2012) ${ }^{5}$ are performed with a duration of pregnancy of less than 12 weeks.

Since 2012, Russia has applied the international definition of live birth, thus abortions in the 22nd-27th weeks of pregnancy were reclassified as "very early preterm births". In 2011, 16 thousand abortions in the 22nd-27th weeks of pregnancy had been registered. 2012 was marked by a slight increase in the number of 12 th-21st week abortions ( 6.6 thousand), apparently due to a partial reclassification of late abortions performed after 21 weeks of pregnancy.

Another innovation deals with the registration of spontaneous abortions. Until 2010, this type of abortion was encoded in Russia as O03 according to ICD-10, and in 2011 an extended code O02-O03 including "missed spontaneous abortion" (O02.1) was introduced. This was done in order to emphasize the "high significance of miscarriage as an important reproductive and demographic issue" [Sukhanova 2013]. Spontaneous abortions (miscarriages), being a type of obstetric pathology, are direct indicators of women's reproductive health.

In one year (from 2011 to 2012), the number of spontaneous abortions in Russia increased from 176.6 to 222.9 thousand, or by $26 \%$, and during pregnancies of less than 12 weeks the number increased from 147.2 to 199 thousand, or by $35 \%$. Such a dramatic increase in the number of reported miscarriages was caused not by the drastic deterioration of reproductive health, but mainly by changes in registration rules. In Russia the transition to a new system of registering spontaneous abortions is probably uneven, in some regions the number of abortions barely changed in 2011-2012, while in others it almost doubled. Hence, a further increase in the number of registered spontaneous abortions nationwide can be expected. The inclusion of miscarriages in the abortion statistics distinguishes Russia from many other countries, and it would be advisable to publish two series of data: the total number of reported abortions and the number of induced abortions (except miscarriages).

The distribution of abortions according to statistical form No.13 for institutions of the Ministry of Health of the Russian Federation is given in Table 4. Most (69\% in 2012) abortions are "medical (legal)" (part of ICD-10 code O04), i.e. hospital abortions performed at the woman's request within 12 weeks of pregnancy, including early abortions performed by vacuum aspiration and pharmaceutical methods (non-surgical method with the use of medicines). The rate (per 1,000

\footnotetext{
${ }^{5}$ No data on abortion distribution by gestation, abortions for medical reasons and abortion methods in institutions outside the system of the Ministry of Health of the Russian Federation.
} 
women of reproductive age) of "medical (legal)" abortions in institutions of the Ministry of Health of the Russian Federation decreased 4.4 times: from 78.9 in 1992 to 17.8 in 2012.

The post-Soviet period is also characterized by a significant decrease of illegal abortions recorded in official statistics ${ }^{6}$ : from 10,157 cases in 1992 to 264 cases in 2012, or equivalent to a 38.5-fold decline per 1,000 women of reproductive age. During the same period, the number of illegal abortions among adolescent girls aged 15-19 decreased from 1,725 to 12, or 144 times. This decrease immediately and positively affected maternal mortality from abortions: according to Rosstat data, in 1992 out-of-hospital abortions resulted in the deaths of 195 women, while in 2012 only 13 women died from that cause. Out-of-hospital abortions are not necessarily illegal, as they may begin spontaneously outside a medical institution. In other words, in Russia the reduction in abortions was accompanied by a significant decline in the risk of death from abortion. Deaths from abortion have been almost completely eliminated.

Table 4. Classification of abortions by the Ministry of Health of the Russian Federation, \% of total number of recorded abortions in the system of the Ministry of Health

\begin{tabular}{l|r|r|r|r|r|r|r}
\hline Abortion & 1992 & 1995 & 2000 & 2005 & 2010 & 2011 & 2012 \\
\hline Spontaneous & 6.32 & 7.23 & 8.87 & 11.20 & 16.36 & 17.85 & 23.83 \\
Therapeutic & 1.45 & 1.74 & 2.15 & 2.84 & 2.70 & 2.94 & 2.63 \\
Illegal & 0.31 & 0.20 & 0.13 & 0.10 & 0.09 & 0.07 & 0.03 \\
Unspecified & 3.46 & 3.73 & 4.28 & 4.84 & 4.93 & 4.81 & 4.56 \\
For social reasons & 0.79 & 1.22 & 2.23 & 0.18 & 0.04 & 0.03 & 0.01 \\
Medical (legal) & 87.67 & 85.86 & 82.34 & 80.84 & 75.88 & 74.30 & 68.93 \\
Total & 100.0 & 100.0 & 100.0 & 100.0 & 100.0 & 100.0 & 100.0 \\
\hline
\end{tabular}

Source: [TsNIIOIZ 2013: 154].

In recent decades, the decline in the number of all types of abortions, except for spontaneous ones, has been accompanied by a redistribution of the contribution of different abortion types to the total number. In 2012, spontaneous abortions accounted for almost a quarter of all abortions in the Ministry of Health of the Russian Federation, while in 1992 their share was only $6 \%$. It should be noted that the rate of spontaneous abortions per 1,000 women of reproductive age began to grow even before the change of registration rules, from about 2006; this was probably due to fertility growth in Russia, including in the older age groups, since the bigger the number of conceptions, the greater the risk of miscarriage.

The year 2006 was marked by a hard-to-explain jump in both the absolute and relative numbers of therapeutic abortions for medical reasons (when the continuation of pregnancy threatens the health of the mother and/or the child) in all age groups under 45. In 2007, the rate returned to the average values for the decade, while in 2008 it decreased significantly and has remained almost unchanged (Figure 6). The last decrease can be related to the 2007 decision on reducing the list of medical indications for abortion (Order of the Ministry of Health and Social Development of the Russian Federation dated December 3, 2007 No.736). Health service officials justified this step in the development of new technologies that make it possible to maintain pregnancy in those women for whom it was previously contraindicated.

\footnotetext{
${ }^{6}$ Criminal abortion is intervention to terminate pregnancy by a pregnant woman by herself or by other persons outside
} the medical institution. 


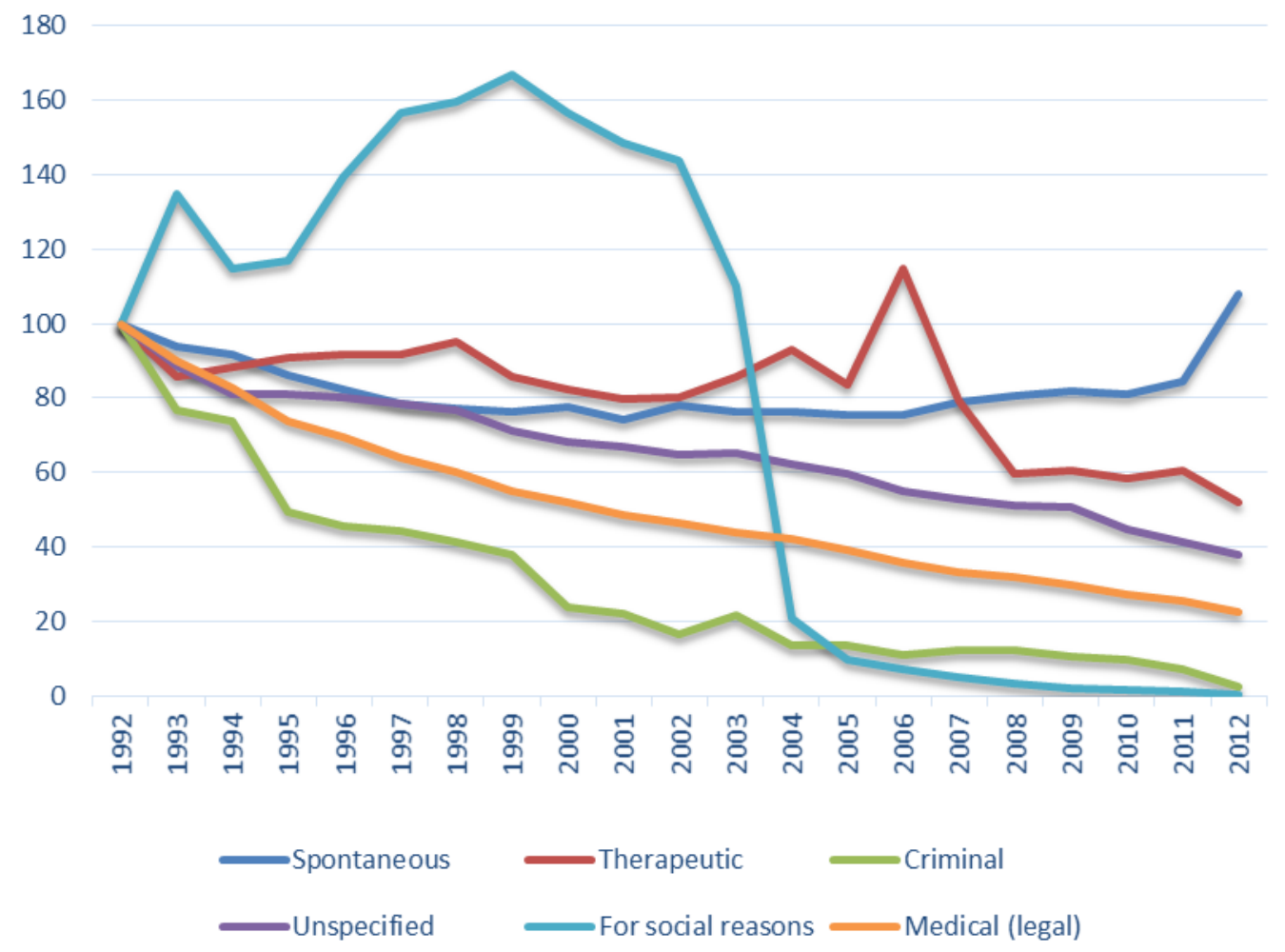

Figure 6. Abortion rate (per 1,000 women of reproductive age) dynamics, 1992=100

Source: Based on the data of the Ministry of Health of the Russian Federation.

The highest variations are typical for abortions performed for social reasons because of changes in the legislation. A broad list of 13 social indications for abortion (Decree of the Government of the Russian Federation dated May 8, 1996 No. 567) was approved in 1996. This measure was intended to eliminate illegal, out-of-hospital abortions amid the difficult socioeconomic conditions of the transition period. In 2003, the Russian Government decided to drastically reduce the list of social indications for abortions to 4 items (Decree dated August 11, 2003 No. 485). Most likely, the transition period in the development of Russia was recognized as completed. In 2012, the Government of the Russian Federation once again reduced the list of social indications for abortion (Decree dated February 6, 2012 No. 98). Today, in the list there is only one item - a pregnancy resulting from a crime committed under Article 131 of the Criminal Code of the Russian Federation (i.e. rape). As a result of legislative reforms, almost no "social" abortions are observed today. In 2012, only 123 abortions for social reasons were recorded, while in 1999 there were 46.5 thousand abortions (maximum level).

According to the WHO, the safest abortion methods for women include vacuum aspiration and pharmaceutical abortion, which are applied in Russia at the early stages of pregnancy only. In 2012, in the public health sector, the proportion of abortions carried out by these safe methods at the early stages of pregnancy reached about one-third $(32.6 \%)$ of all abortions carried out at the woman's request within the first 12 weeks of pregnancy, including $8 \%$ of cases when medical 
drugs were used. ${ }^{7}$ Most abortions in the facilities of the Ministry of Health are performed by surgical curettage, which is recognized by the WHO as an obsolete method that should be used in exceptional cases only [WHO 2013: 31].

According to SSRH (see footnote 4), the proportion of vacuum and pharmaceutical abortions is higher in 2006-2011 than according to the Ministry of Health of the Russian Federation: $33.8 \%$ and $7.7 \%$, respectively. But in both cases, most (55\%) pregnancies were terminated using the "obsolete" and more traumatic method of curettage [Rosstat 2013a: 59].

It is no wonder that Russian medical literature has been dominated by the view of abortion as a crippling operation. The consequences of abortion were described in the Soviet period as follows: "Almost one in three women suffers from complications after abortion, and in the case of a first pregnancy, almost one in two is affected. Abortion results in emotional stress which breaks the course of all mental and physical processes in the body, affects the course and outcome of subsequent pregnancies. Abortion has been found to be the main source of gynecological diseases. ...Scientific literature is full of data on the risk of female genitalia cancer rising parallel to the rate of induced abortions" [Shneyderman 1991: 60]. Today, medical doctors continue to insist on the disastrous results of legal abortions for women's health - a claim unproven by research. According to O.V. Sharapova (one-time Deputy Minister of Health of the Russian Federation), "The frequency of early, delayed and long-term complications after abortions... is in the range of 16$52 \%$, and the late complications, mainly more disastrous, are considerably more numerous than the earlier ones..." [Sharapova, Baklaenko 2003]. The Order of the Ministry of Health and Social Development of the Russian Federation dated May 17, 2007 No. 335 recommends alerting women seeking abortion within 12 weeks of conception about possible long-term consequences of abortion such as infertility, ectopic pregnancy, premature birth, neuro-psychiatric disorders, etc. As was mentioned earlier, evidence-based medical science does not confirm the "horror stories" of health service officials, provided that the abortion is performed by qualified personnel complying with all required standards.

It is clear that the current objective of the Russian health service is to improve the safety and quality of abortion, as well as to introduce safe medical technologies. Does the "waiting week" introduced in 2012 by the new law "On Fundamental Healthcare Principles in the Russian Federation" (Law No. 323 dated November 21, 2011) at least somewhat contribute to such improvements? The "waiting week" is a specific period given to a woman to reconsider her decision to abort. The length of this period depends on the stage of pregnancy: at 4-7 weeks and 11-12 weeks after conception the abortion may be conducted no earlier than 48 hours after the first visit to the clinic; at 8-10 weeks after conception the abortion may be conducted no earlier than 7 days after visiting the clinic. During this time, it is recommended that the woman undergo a psychological consultation, the main purpose of which is to make the woman change her decision, maintain pregnancy and give birth. But due to the fact that gentle abortion methods are allowed only at very early stages of pregnancy, waiting too long can result in the impossibility of using them. As a result, safe and healthy methods of abortion are becoming even less available in Russia.

\footnotetext{
${ }^{7}$ In Russia, medicines for medical abortion are available in licensed medical institutions, including private clinics, but there are no published data on pharmaceutical abortions in private clinics.
} 


\section{Abortion, Contraception and Fertility}

Fertility is the product of proximate determinants such as fecundity, frequency of intercourse and conscious birth control. The decomposition of fertility into its proximate determinants was proposed by J. Bongaarts and was named the Bongaarts model [Bongaarts 1978; 1982]. The essence of this approach is that socio-economic and other factors affect fertility through these (proximate) variables. For example, one's level of education affects the number and timing of births indirectly, through getting (or not getting) married, using (or not using) contraception, and the acceptability of abortion. Bongaarts' approach makes it possible to distinguish family planning from birth control; the latter, in addition to contraception methods, includes the termination of pregnancy (abortion). The use of contraception to prevent unwanted conception and abortion to prevent an unwanted birth if conception has already occurred, are different ways to achieve a desired number of children in the family.

A general form of the model is as follows [Bongaarts 1978]

$$
F=C_{m} \cdot C_{i} \cdot C_{a} \cdot C_{c} \cdot F_{p}
$$

Where fertility $(F)$ is calculated through fecundability $\left(F_{p}\right)$ dependent on four factors: exposure to risk of conception measured as proportion married $\left.C_{m}\right)$; the duration of postpartum infecundability caused by breastfeeding $\left(C_{i}\right)$; frequency of abortion $\left(C_{a}\right)$; use of contraception $\left(C_{c}\right)$ which in turn can be subdivided into separate methods (hormonal, barrier, etc.). Later, a fifth index was added to the model - permanent sterility or infertility $\left(C_{S}\right)$ [Bongaarts et al. 1984]. $(C)$ indices range from 0 to 1 ; if the factor does not affect fertility, the index is equal to 1 ; the lower the value of the index, the greater the effect of the relevant factor on fertility deviation from potential fertility.

The application of Bongaarts' model to Russia was impeded by the unavailability of necessary data. The results of the 19th wave of RLMS-HSE (2010) made it possible to estimate the proximate determinants of fertility, as well as to check the adequacy of the survey data on birth control. In order to verify the rationality of the respondents' answers, we restated the problem: we did not calculate the birth rate based on proximate determinants, rather, we estimated the hypothetical potential fertility performance based on known fertility and calculated Bongaarts' indices. In other words, the formula (1) was transformed as follows: $F_{p}=\frac{F}{C_{m} \cdot C_{i} \cdot C_{a} \cdot C_{c} \cdot C_{s}}$.

\footnotetext{
${ }^{8}$ Indices are calculated with the following formulae: $C_{m}=\frac{\sum m(a) \cdot g(a)}{\sum g(a)}$, where $m(a)$ is the age-specific proportions of women in partnership, $g(a)$ is age-specific marital fertility; $C_{i}=\frac{20}{18.5+i}$, where $i$ is the average duration of postpartum infecundability; $C_{a}=\frac{F}{F+0.4 \cdot(1+u) \cdot T A R}$, where $u$ is the contraception prevalence (proportion of women in partnership who are fecund and using contraception), $T A R$ is the total abortion rate; $C_{c}=1-1,08 \cdot u \cdot e$, where $e$ is the average efficiency of contraception; and $C_{s}=\frac{(7.63-0.11 \cdot s)}{7.3}$, where $s$ is the proportion of childless women aged 45-49. In this case, we used a modified formula proposed by Stover [Stover 1998]: $C_{s}=1-f$, where $f$ is the proportion of women of reproductive age who have fertility issues.
} 
The calculation results are given in Table 5. Since obtaining indices requires a range of assumptions, ${ }^{9}$ the ratios of indices, rather than the indices themselves, are important.

Table 5. Bongaarts' indices based on the 19th wave of RLMS-HSE (2010)

\begin{tabular}{|l|r|}
\hline Total fertility of the synthetic cohort, children per woman, $F$ & 1.274 \\
Index of proportion married, $C_{m}$ & 0.574 \\
Postpartum infecundability index, $C_{i}$ & 0.841 \\
Abortion index, $C_{a}$ & 0.665 \\
Permanent sterility index, $C_{s}$ & 0.879 \\
Contraception index, $C_{c}$ & 0.291 \\
Fecundability, children per woman, $F_{p}$ & 15.503 \\
\hline Total marital fertility rate, children per woman, TMFR & 2.116 \\
Contraceptive prevalence, per woman, $u$ & 0.806 \\
Efficiency of contraception, index, $e$ & 0.815 \\
Total abortion rate, abortions per woman, TAR & 0.887 \\
Average duration of exclusive breastfeeding, months & 5 \\
\hline
\end{tabular}

Notes: The marital fertility rate for the age group of 15-19 was assumed to equal 30\% of the marital fertility rate in the age group of 20-24. Contraception prevalence refers to sexually active women who do not plan to bear a child. The total abortion rate was increased by $15 \%$ to allow for spontaneous abortions. Data on the infertility prevalence (12.1\%) were based on the survey "Parents and Children, Men and Women in Family and Society" conducted in 2007 [Sakevich 2009: 132-133].

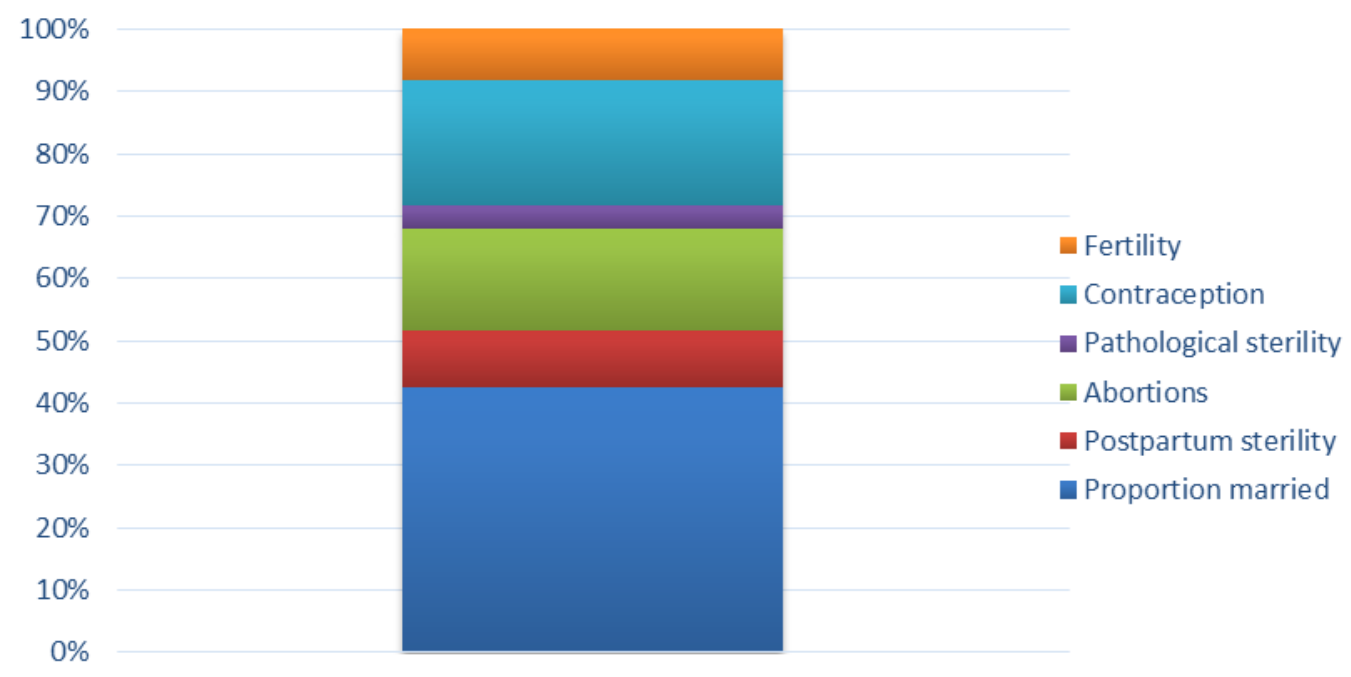

\section{Figure 7. Bongaarts' proximate determinants of Russian fertility (\% of total fecundability of 15.5 children per woman)}

Source: Author's calculations based on the results of the 19th wave of RLMS-HSE (2010)

(URL: http://www.hse.ru/rlms/).

As follows from Table 5 and Figure 7, sexual exposure is the single most important factor depressing fecundability into observed fertility. Since not all women of reproductive age are in a partnership throughout the reproductive period, the birth rate is less than the potential fertility performance by approximately $40 \%$. Contraception and abortion significantly affect fertility in

\footnotetext{
9 For example, following Bongaarts' logic, we excluded extramarital births and abortions from the calculation, although extra-marital conception is not uncommon today. Moreover, equating the status of married (including unregistered) women with the status of sexually active women is not correct.
} 
marriage or partnership. Contraception has a greater effect than abortion. The role of abortion in birth control is decreasing. Thus, the abortion index calculated for the Russian population in the early 1990s was at 0.562 [Entwisle, Kozyreva 1997: 20], whereas in 2010 it reached 0.665. The effect of infertility on the total fertility rate is low.

Fecundability of Russian women equals 15.5 births, which is close to Bongaarts' estimate of fecundability - 15.3 births per woman on average (varying from 13 to 17). Thus, all components of the model based on our data - proximate determinants of fertility estimated on the basis of RLMS-HSE 2010 - are consistent among themselves and with observed fertility. This confirms the validity of the survey results and the appropriateness of using them to assess the reliability of official abortion statistics.

\section{CONCLUSIONS}

The number of abortions in Russia has decreased steadily throughout the post-Soviet years. This is confirmed by both official statistics and surveys. The rapid decline of abortion is particularly pronounced among young women. Russia lost its deplorable leadership in this domain and now has a lower frequency of teenage abortions than many Westerns countries. The "abortion culture", if it existed, belongs to the past. According to Bongaarts' model, the role of contraception as a method of birth control in present-day Russia is far superior to the role of induced abortions. The efficiency of family planning is improving.

Yet, in the 2000s, the rate of decline in the number of terminated pregnancies slowed down. Today, Russia lags behind neighboring countries, which in the Soviet period had the same rates as Russia but have considerably bypassed it in reducing the prevalence of abortion. As a result, Russia remains among the countries with the highest abortion rates in the world (this assessment is valid for countries with complete abortion statistics that constitute one-third of the total).

In addition to overcoming this lag, the current objectives of the Russian health care service are to improve the safety and quality of abortion services, introduce modern medical standards and, in particular, promulgate the use of safe methods such as pharmaceutical abortion.

Improving the quality of medical care implies, inter alia, increasing its availability. Meanwhile, in Russia, the last 10-15 years have been marked by a number of new legislative amendments limiting the availability of abortion, including at early pregnancy. These amendments include a reduction in the list of medical and social indications for abortion, the introduction of a "waiting week" - a mandatory waiting period between "applying" for an abortion and the procedure - and a ban on advertising abortion services. The exclusion of abortion from the basic program of compulsory health insurance is under active discussion.

Russia's lagging behind other countries in reducing the prevalence of abortion is apparently causing concern among health service officials, making them seek more effective methods to solve the abortion issue. But against the background of Russia's turn towards "traditional" principles and values, and of the strengthening of the role of the Church in society, repression and restrictions, rather than empirically well-founded, effective measures (e.g. promotion of family planning, sex education), are increasingly preferred. 
Legislative restriction of abortion is regarded as a tool to increase fertility. This is periodically stated by officials who interpret the prevention of abortion as its outright rejection in favor of birth, even if the pregnancy is unwanted. One of the target indicators of the Russian State Program for Health Development (adopted by Order of the Government of the Russian Federation No. 2511-r dated December 24, 2012) is the proportion of women seeking abortion at a medical institution who were persuaded not to terminate the pregnancy. This proportion should increase to $15 \%$ by 2020 , but the estimation method was not specified.

Demographers are well aware of the historical experience of countries where abortion has been outlawed (Nazi Germany, Communist Romania, Stalin's USSR, and present-day Poland). This measure was not characterized by positive demographic effects; on the contrary, it resulted in increased maternal mortality and even in a number of infanticides.

Hence, recent Russian legislative innovations are not contributing to a rapid decrease of the number of abortions (actually the decrease is slowing down, as noted above), and even may exert a negative effect on reproductive health.

Finally, the state of Russian abortion statistics should be considered. On the one hand, there is no reason to doubt its accuracy and completeness. On the other hand, the official statistics of terminated pregnancies need to be improved in terms of detailing the indicators. In contrast to most countries with official statistics on abortions, Russian statistics include miscarriages or spontaneous abortions; the data on the subdivision of abortions into induced abortions and miscarriages should be published and taken into account in international comparisons. One more disadvantage of official abortion statistics is the fact that they provide a limited number of sociodemographic characteristics of women undergoing abortion.

The last few years have been marked by the emergence of extensive sets of data on the reproductive behavior and health of Russians generated by national representative surveys. There is hope for significant progress in understanding the situation and its problems, including those related to overcoming Russia's "leadership" in abortion.

\section{REFERENCES}

Avdeev A., A. Blum, I. Troitskaja (1995). The history of abortion statistics in Russia and the USSR from 1900 to 1991 // Population: An English Selection. 7.

Bongaarts J. (1978). A framework for analyzing the proximate determinants of fertility // Population and Development Review. 4: 105-131.

(1982). The fertility-inhibiting effects of the intermediate fertility variables // Studies in Family Planning. 13 (6/7): 179 - 189.

Bongaarts J., O. Frank, R. Lesthaeghe (1984). The proximate determinants of fertility in subSaharan Africa // Population and Development Review. 10: 511-537.

Currie C. et al. (2012). Social determinants of health and well-being among young people. Health Behaviour in School-aged Children (HBSC) study: international report from the 2009/2010 survey. Copenhagen: WHO Regional Office for Europe. 
Denisov B., V. Sakevich, A. Jasilioniene (2012). Divergent trends in abortion and birth control practices in Belarus, Russia and Ukraine // PLoS ONE 7(11): e49986.

doi:10.1371/journal.pone.0049986

Denisov B.P., V.I. Sakevich [Денисов Б.П., В.И.Сакевич] (2009). Aborty v Rossii (po materialam vyborochnogo obsledovaniya [Abortion in Russia (based on a sample survey)] // Dokazatel'naya meditsina i klinicheskaya epidemiologiya [Evidence-based medicine and clinical epidemiology]. № 2.

Entwisle B., P. Kozyreva (1997). New estimates of induced abortion in Russia // Studies in Family Planning. 28 (1): 14-23.

Eurostat Database. URL:

http://epp.eurostat.ec.europa.eu/portal/page/portal/population/data/database (accessed: 21.02.2014).

National statistical committee of the Republic of Belarus [Национальный статистический комитет Республики Беларусь] (2013). Statisticheskij ezhegodnik Respubliki Belarus' [Statistical yearbook of the Republic of Belarus]. Minsk: National statistical committee of the Republic of Belarus.

Philipov D., E. Andreev, T. Kharkova, V. Shkolnikov (2004). Induced abortion in Russia: recent trends and under-reporting in surveys // European Journal of Population. 20: 95-117.

Radzinsky V.Е. [Радзинский B.E.] (2013). Regulirovaniye rozhdayemosti v sovremennom mire [Birth control in the modern world] // StatusPraesens. Ginekologiya, Akusherstvo, Besplodnyy brak [StatusPraesens. Gynecology, Obstetrics, Infertile marriage]. 2(13).

Rosstat [Росстат] (2013a). Final report Reproductive health of the Russian population 2011. M.: Rosstat, Ministry of health (Russia), UNFPA, CCD, Information and publishing center Statistics of Russia.

(2013b). Healthcare in Russia 2013. Statistical issue. M.: Rosstat.

Sakevich V.I. [Сакевич В.И.] (2009). Osobennosti vnutrisemeynogo kontrolya rozhdayemosti v Rossii [Features of the birth control in Russia] // S.V. Zaharov, T.M. Maleva, O.V.

Sinyavskaya, eds. Roditeli i deti, muzhchiny i zhenshchiny v sem'ye i obshchestve. [Parents and children, men and women in family and society]. Moskva: NISP: 119-138.

- (2011).Rossiya idet k zapretu aborta? [Russia is to ban abortion?] // Demoscope Weekly. № 479-480. URL: http://demoscope.ru/weekly/2011/0479/reprod01.php (accessed: 22.01.2014).

(2012). Novyye ogranicheniya prava na abort v Rossii [New restrictions on abortion rights in Russia] // DemoscopeWeekly. № 499-500. URL:

http://demoscope.ru/weekly/2012/0499/reprod02.php (accessed: 22.01.2014).

(2013). Obshchestvennaya diskussiya o legitimnosti aborta v Rossii prodolzhayetsya

[Public discussion about the legitimacy of abortion continues in Russia] // Demoscope

Weekly. №577-578. URL: http://demoscope.ru/weekly/2013/0577/reprod01.php (accessed: 22.01.2014).

Sedgh G., S. Singh, S.K. Henshaw, A. Bankole (2011). Legal abortion worldwide in 2008: levels and recent trends // International Perspectives on Sexual and Reproductive Health. 37 (2): 84-94.

Sharapova O.V., N.G. Baklaenko [Шарапова O.В., Н.Г. Баклаенко] (2003). Medikosotsial'nyye i pravovyye aspekty abortov v Rossiyskoy Federatsii [Medico-social and legal aspects of abortion in the Russian Federation] // Planirovaniye sem'i [Family Planning]. № 3. 
Shneyderman N.A. [Шнейдерман H.A.] (1991). Otkrovennyy razgovor: rozhdayemost' i mery yeye regulirovaniya [Straight talk: Fertility and its control measures]. Moskva: Mysl'.

Stover J. (1998). Revising the proximate determinants of fertility framework: what have we learned in the past 20 years? // Studies in Family Planning. Vol. 29, No. 3: 255 - 267.

Sukhanova L.P. [Суханова Л.П.] (2013). Statistical information about the state of the problem of abortion and infertility in the Russian Federation. Analytical report. M.: FGBU TSNIIOIZ, Ministry of Health (Russia).

TsNIIOIZ [Tsentral'nyy nauchno-issledovatel'skiy institut organizatsii i informatizatsii zdravookhraneniya] (2013). Osnovnye pokazateli zdorov'ya materi i rebenka, deyatel'nost' sluzhby okhrany detstva i rodovspomozheniya v Rossijskoj Federatsii [Key indicators of maternal and child health, child protection and obstetrics services in the Russian Federation]. Statisticheskij sbornik [Statistical issue]. Moskva: Federal Research Institute for Health Organization and Informatics of Ministry of Health of the Russian Federation.

UNICEF (2013). Transformative Monitoring for Enhanced Equity (TransMonEE) database. URL: http://www.transmonee.org/index.html (accessed: 22.02.2014).

Vishnevsky A.G., V.I. Sakevich [Вишневский А.Г., В.И. Сакевич] (2006). Rossiya mezhdu abortom i planirovaniyem sem'i [Russia between abortion and family planning] // Demograficheskaya modernizatsiya Rossii, 1900-2000 [Demographic modernization of Russia, 1900-2000]. Moskva: Novoye izdatel'stvo: 195-246.

WHO (2013). Safe abortion: Guidance for Health Systems as to Policy and Practice. The second edition. The World Health Organization, Department of Reproductive Health and Research. 